\title{
Kajian Psikolinguistik Sebagai Representasi Pemerolehan Bahasa Kedua Mahasiswa Program Darmasiswa di Ikip Budi Utomo Malang
}

\author{
Azza Aulia Ramadhani ${ }^{(1)}$, Nurwakhid Muliyono ${ }^{(2)}$, Endang Setyowati ${ }^{(3)}$ \\ 1,2,3 IKIP Budi Utomo Malang, Indonesia \\ Email: 1'azzauliaramadhani@gmail.com, \\ 2nurwakhidmuliyono@gmail.com, ${ }^{3}$ hafendangsetyowati605@gmail.com
}

\begin{tabular}{l}
\hline Tersedia Online di \\
http://www.jurnal.unublitar.ac.id/i \\
ndex.php/briliant
\end{tabular}

Sejarah Artikel

Diterima pada 5 November 2019

Disetujui pada 12 November 2019

Dipublikasikan pada 30

November 2019 Hal. 473-481

Kata Kunci:

Pemerolehan B2, SLA, BIPA,

Darmasiswa

\section{DOI:}

http://dx.doi.org/10.28926/briliant. v3i4.403

\begin{abstract}
Abstrak: Tujuan penelitian ini untuk mengetahu proses pemerolehan bahasa kedua, tingkat penguasaan bahasa kedua, dan representasi hasil belajar bahasa kedua mahasiswa asing program Darmasiswa di IKIP Budi Utomo Malang. Data dikumpulkan dengan dokumentasi, kemudian data dianalisis dengan teknik deskriptif dan kualitatif. Hasil penelitian ini adalah ditemukan (1) proses pemerolehan bahasa kedua mahasiswa asing yang berlangsung secara sadar dan alamiah; (2) tingkat penguasaan bahasa kedua mahasiswa asing yang dapat dilihat pada penguasaan empat aspek keterampilan berbahasa; dan (3) representasi hasil belajar bahasa kedua mahasiswa asing yang ditandai dengan penguasaan fonologis, sintaksis, dan semantik..
\end{abstract}

\section{PENDAHULUAN}

Bahasa Indonesia bagi penutur asing, atau sering dikenal dengan sebutan BIPA merupakan salah satu ranah Bahasa Indonesia dan pembelajarannya yang diprogramkan khusus bagi pelajar asing (Suyitno, 2017:1). Karakteristik wujud BIPA ditentukan oleh karakteristik mahasiswa asing yang mempelajarinya. Oleh karena itu, proses pemerolehan bahasa mahasiswa asing juga ditentukan oleh masing-masing karakteristiknya, dilihat dari latar belakang bahasa pertama yang dimiliki oleh mahasiswa asing. Mengingat mahasiswa yang datang ke Indonesia untuk belajar Bahasa Indonesia berasal dari berbagai negara.

Sammeng (dalam Suyitno, 2017:3) mengemukakan bahwa pembelajaran BIPA di Indonesia memiliki peranan penting apabila dikaitkan dengan posisi Indonesia dalam percaturan dunia yang semakin hari semakin penting. Dibukanya pasar kerja di Indonesia memperbesar peluang bagi orang asing untuk memasuki wilayah Indonesia. Untuk dapat memperoleh lapangan kerja di Indonesia, orangorang asing berupaya mempelajari Bahasa Indonesia agar dapat berkomunikasi lebih baik dengan pejabat, sejawat, karyawan ataupun masyrakat umum Indonesia. 
Salah satu program pembelajaran BIPA yang dilaksanakan oleh pemerintah dalam rangka untuk mempromosikan dan meningkatkan ketertarikan terhadap bahasa, seni, dan budaya Indonesia di kalangan generasi muda di negara lain yang memiliki hubungan diplomatik dengan Indonesia adalah program Darmasiswa. Program Darmasiswa ini sendiri adalah program beasiswa tanpa gelar. Sebanyak 53 perguruan tinggi di Indonesia ditunjuk oleh pemerintah untuk melaksanakn program Darmasiswa. Program ini merupakan program kerjasama Kementerian Pendidikan dan Kebudayaan serta Kementerian Luar Negeri yang telah dilaksakan sejak tahun 1974 (Kemendikbud, 2015).

Hingga saat ini jumlah negara yang ikut berpartisipasi dalam program Darmasiswa lebih dari 75 negara (Kemendikbud, 2015). Dengan demikian, mahasiswa asing yang ikut berpartisipasi dalam program Darmasiswa tentunya berasal dari berbagai negara yang memiliki karakteristik dan budaya yang berbeda. Maka, proses pemerolehan bahasa yang dialami oleh masing-masing mahasiswa berbeda pula tentunya karena proses pemerolehan bahasa dipengaruhi oleh bahasa ibu penutur asing. Hal tersebut didukung oleh pendapat Suyitno (2017:37) yang menyatakan bahwa pelajar BIPA adalah pelajar asing yang berasal dari berbagai negara. Oleh karena itu, mereka memiliki latar belakang bahasa dan budaya yang berbeda dengan bahasa dan budaya Indonesia. Selain itu, mereka juga memiliki latar belakang pengetahuan dan keterampilan berbahasa Indonesia yang bervariasi. Bahkan, gaya dan strategi belajarnya pun sangat bervariasi dan sangat bergantung pada budaya mereka masing-masing. Hal tersebut tentunya berpengaruh terhadap proses pemerolehan bahasa yang dialami setiap mahasiswa asing. Oleh karena itu, dibutuhkan analisis kajian psikolinguistik untuk membedah proses pemerolehan bahasa setiap mahasiswa.

Secara umum, mahasiswa asing yang belajar di Indonesia adalah pembelajar dewasa. Mereka adalah pelajar yang rata-rata telah berusia 17 tahun ke atas. Dengan demikian, proses pemerolehan bahasa yang mereka alami tentu berbeda dengan proses pemerolehan bahasa pada anak yang dimulai dengan mendengarkan bunyi lalu menirukan. Oleh karena itu, dibutuhkan analisis tersendiri untuk menilai perkembangan bahasa mahasiswa asing. Terutama mahasiswa asing program Darmasiswa yang belajar di IKIP Budi Utomo Malang.

Perkembangan pemerolehan Bahasa Indonesia mahasiswa asing dapat dilihat dari produksi bahasa yang dihasilkan. Perkembangan pemerolehan bahasa tentunya dapat dilihat dari hasil belajar, baik secara lisan maupun tulisan. Produksi ujaran yang dihasilkan dapat dikaji dengan bidang keilmuan psikolingustik karena kemajuan berbahasa seseorang juga dapat dilihat dari faktor psikologisnya. Faktor psikologis mahasiswa asing tentunya dipengaruhi oleh faktor internal maupun eksternal. Faktor internal berasal dari diri mahasiswa asing sendiri dan faktor eksternal berasal dari lingkungan sekitar mahasiswa asing.

Berdasarkan alasan-alasan yang telah disebutkan di atas, maka penelitian tentang pemerolehan bahasa yang dikaji dengan bidang keilmuan psikolinguistik perlu dilakukan. Setiap mahasiswa asing peserta program Darmasiswa berasal dari negara yang berbeda. Tentu saja hal tersebut melatarbelakangi perbedaan proses pemerolehan bahasa mereka sehingga tingkat penguasaan Bahasa Indonesia mereka juga berbeda meskipun belajar dalam satu kelas yang sama. Hal tersebut tentu berpengaruh pada ujaran-ujaran yang mereka produksi. Oleh karena itu, 
diperlukan analisis mendalam untuk mengetahui tingkat penguasaan bahasa mahasiswa asing peserta program Darmasiswa.

\section{METODE}

Penelitian ini bertujuan untuk mendeskripsikan hasil pemerolehan bahasa kedua oleh mahasiswa asing dalam program Darmasiswa di IKIP Budi Utomo Malang. Hasil pemerolehan bahasa kedua tersebut diwujudkan dalam penggunaan ragam bahasa tertentu, serta disampaikan melalui pola dan strategi tertentu pula. Selain itu, pemerelohan bahasa kedua setiap individu memiliki keunikan tersendiri dan tingkat penguasaan bahasa setiap individu juga tidak sama. Berdasarkan tujuan tersebut, maka penelitian ini menggunakan rancangan penelitian kualitatif.

Pemilihan rancangan penelitian ini didasari oleh dua pertimbangan. Pertama, data penelitian ini bersifat alamiah, yaitu data diambil dari proses pembelajaran dalam kelas, yaitu berupa kata, kalimat, kosakata, dan bentuk tuturan oleh mahasiswa asing program Darmasiswa di IKIP Budi Utomo Malang, sehingga data-data tersebut tidak dapat dimanipulasi. Hal ini sesuai dengan pendapat Thomas (2003:1), yang mengemukakan bahwa "qualitative researchers study things in their natural setting, attempting to make sense of, or interpret phenomena in term of the meaning people bring to them". Dalam pernyataan tersebut, Thomas mengemukakan bahwa dalam penelitian kualitatif, peneliti mempelajari sesuatu hal di latar alamiahnya, berusaha untuk memahami atau menafsirkan fenomena sesuai dengan pemahaman masyarakat tentang hal tersebut. Kedua, penelitian ini bersifat deskriptif, yaitu berusaha membuat deskripsi secara sistematis, faktual dan akurat mengenai fakta-fakta, sifat-sifat, serta hubungan antarfenomena yang diselidiki. Penulisan saran dipandang sebagai salah satu fenomena penggunaan bahasa di lingkungan ilmiah yang dapat dideskripsikan secara sistematis, sesuai dengan rumusan masalah yang diteliti.

Subjek penelitian ini adalah mahasiswa asing program damasiswa di IKIP Budi Utomo Malang. Dalam satu kelas terdapat 6 mahasiswa asing, yang berasal dari negara: Afghanistan, Jerman, Thailand, Italia, Polandia, dan Ukraina. Sumber data penelitian ini berupa: lembar hasil observasi, transkrip wawancara, placement test, tes A1, A2, dan B1. Data yang berasal dari hasil observasi, hasil wawancara, dan hasil tes yang dianalisis dengan diskripsi kualitatif.

Instrumen penelitian untuk menumpulkan data adalah lembar observasi, panduan wawancara, dan tes tulis. Kemudian, teknik pengumpulan datanya akan dilakukan dengan cara observasi, wawancara dengan para dosen pengajar program Darmasiswa dan focus group discussion (FGD).

Analisis data dalam penelitian ini dilakukan dengan tahap pengidentifikasian, yaitu peneliti mengidentifikasi data hasil observasi, wawancara, dan tes mahasiswa asing dengan cara menyeleksi dan memilih data yang benar-benar layak digunakan. Kemudian, peneliti mengklasifikasi data berdasarkan aspek fonologis, sintaksis, dan semantik. Setelah itu, data disajikan dalam tabel dan diberi kode. Lalu pada tahap akhir peneliti menyimpulkan hasil akhir penelitian.

\section{HASIL}


Ada tiga hasil dalam penelitian ini, yaitu (a) ditemukan proses pemerolehan bahasa kedua mahasiswa asing proram Darmasiswa di IKIP Budi Utomo Malang berdasarkan hasil pengamatan pembelajaran di dalam dan di luar kelas selama 10 bulan program Darmasiswa berlangsung; (b) ditemukan tingkat penguasaan bahasa mahasiswa asing program Darmasiswa berdasarkan hasil pengamatan pada nilai placement test, tugas harian, tes $\mathrm{A} 1$, tes $\mathrm{A} 2$, dan tes $\mathrm{B} 1$ mahasiswa asing; dan (c) ditemukan representasi hasil belajar mahasiswa asing program Darmasiswa berdasarkan hasil pengamatan dan wawancara pada pengajar BIPA. Adapun hasil penelitian yang lebih lengkap dalam penelitian ini adalah sebagai berikut.

Pertama, proses pemerolehan bahasa kedua mahasiswa asing program Darmasiswa di IKIP Budi Utomo Malang dilalui dengan belajar bahasa secara sadar, yaitu dengan mengikuti kegiatan belajar mengajar di dalam kelas selama kurang lebih 10 bulan. Selain belajar Bahasa Indonesia secara formal di dalam kelas, mahasiswa asing juga belajar secara nonformal di luar kelas dalam kegiatan outdoor class yang dilaksanakan satu kali dalam sebulan. Selain itu, mahasiswa asing program Darmasiswa juga dituntut secara aktif belajar mandiri melalui tugas rumah yang diberikan oleh pengajar. Proses pemerolehan bahasa kedua mahasiswa asing juga didapat dengan belajar secara mandiri dengan berkomunikasi langsung dengan orang-orang yang berada di lingkungan sekitar tempat tinggal mahasiswa asing. Dengan demikian, mahasiswa asing program Darmasiswa akan memeroleh berbagai input dari lingkungan masyarakat Indonesia, di samping dari pengajar, buku, atau media informasi lain. Sebab, bahasa Indonesia merupakan bahasa utama atau bahasa dominan di Indonesia, maka ketika ke luar kelas, para mahasiswa asing akan berinteraksi dengan bahasa tersebut. Dalam hal ini, mahasiswa asing akan melakukan proses reseptif dan produktif dalam belajar bahasa Indonesia. Dalam situasi tersebut, Bahasa Indonesia dapat dikatakan sebagai bahasa kedua.

Kedua, tingkat penguasaan bahasa kedua mahasiswa asing meningkat seiring dengan berjalannya waktu. Hal tersebut dapat dilihat dari hasil pengamatan selama 10 bulan saat berlangsungnya program Darmasiswa. Perkembangan tingkat penguasaan bahasa Indonsesia mahasiswa asing dapat diamati dari hasil tulisan yang tertuang dalam placement test, tugas harian, tes A1, A2, dan B2. Pengamatan dilakukan pada empat aspek keterampilan berbahasa yang terdiri atas membaca, menulis, berbicara, dan mendengarkan. Selain itu, pengamatan juga dilakukan pada kemampuan mahasiswa asing dalam menerapkan kaidah Bahasa Indonesia yang telah diajarkan di dalam kelas. Perkembangan kemampuan berbahasa mahasiswa asing tampak pada semakin banyaknya kosakata yang dikuasai, kemampuan menyusun kalimat, dan kemampuan dalam menyusun teks sedehana.

Ketiga, representasi hasil belajar mahasiswa asing program Darmasiswa ditandai dengan semakin banyaknya kosakata yang dikuasai mahasiswa asing, penguasaan dalam penggunaan tata bahasa, penyusunan kalimat yang sesuai kaidah, pengucapan yang sesuai dengan kaidah berbahasa Indonesia, dan penyusunan teks sederhana. Representasi hasil belajar mahasiswa ini didapat dari hasil pengamatan selama 10 bulan berlangsungnya program Darmasiswa, hasil placement test, tugas harian, tes $\mathrm{A} 1, \mathrm{~A} 2$, dan B2. Tes yang dilakukan tersebut tercakup dalam empat aspek keterampilan berbahasa, yaitu membaca, menulis, 
berbicara, dan mendengarkan. Ada pula tes tulis tata Bahasa Indonesia yang dilakukan untuk mengukur tingkat penguasaan mahasiswa asing dalam menggunakan Bahasa Indonesia yang sesuai dengan kaidah.

\section{PEMBAHASAN \\ Proses Pemerolehan Bahasa Kedua Mahasiswa Asing Program Darmasiswa di IKIP Budi Utomo Malang}

La Porge (dalam Tarigan, 2011:142) mengemukakan bahwa ada tiga hal yang dapat dianggap sangat penting dan dasar dalam pemerolehan bahasa kedua (B2), yaitu (1) belajar bahasa adalah orang; (2) belajar bahasa adalah orang-orang dalam interaksi dinamis; dan (3) belajar bahasa adalah orang-orang dalam responsi. Dalam belajar bahasa, terkandung makna bahwa hal itu proses sosial belajar yang utama. Belajar, pemerolehan B2, terjadi dalam hubungan antarpribadi antara pengajar dan sekelompok mahasiswa, dan juga hubungan antarsesama mahasiswa itu sendiri. Interaksi dinamis berarti bahwa orang-orang dilahirkan dan bertumbuh dalam bahasa asing. Hubungan antara pengajar dan mahasiswa akan berubah bila mahasiwa berkembang dalam bahasa. Interaksi dinamis berarti bahwa sang pengajar memberikan atau menyediakan pengalamanpengalaman belajar yang bermanfaat yang memenuhi kebutuhan-kebutuhan para mahasiswa dalam berbagai tahap perkembangan mereka. Di samping itu, belajar bahasa merupakan responsi para mahasiswa.

Sejalan dengan hal tersebut, Tarigan (2011:142) menambahkan bahwa pemerolehan bahasa menuntut interaksi yang berarti dalam bahasa sasaran (target language) komunikasi alamiah yang merupakan wadah para pembicara memerhatikan bukan bentuk ucapan-ucapan mereka, tetapi pesan-pesan yang mereka sampaikan dan mereka pahami. Sama halnya dengan proses pemerolehan bahasa kedua mahasiswa asing program Darmasiswa di IKIP Budi Utomo Malang yang tidak memerhatikan kaidah dalam proses menghasilkan ujaran. Pengajar mata kuliah Berbicara di program Darmasiswa menyatakan bahwa yang diutamakan adalah keberanian mahasiswa asing dalam berujar menggunakan Bahasa Indonesia tanpa memerhatikan kaidah untuk sementara waktu agar mahasiswa memiliki kepercayaan diri untuk menggunakan Bahasa Indonesia yang telah mereka pelajari. Kaidah kebahasaan dapat dipelajari dan diperbaiki saat proses pembelajaran berlangsung.

Proses kegiatan belajar mengajar Bahasa Indonesia di program Darmasiswa tidak hanya berlangsung di dalam kelas, tetapi juga berlangsung di luar kelas dalam kegiatan outdoor class. Dalam kegiatan outdoorclass tersebut mahasiswa asing diajak untuk mengunjungi tempat-tempat bersejarah di Kota Malang, seperti Candi Badut, Candi Singosari, dan Meseum Brawijaya. Selain diajak berkunjung ke tempat-tempat bersejarah, mahasiswa asing juga diajak ke beberapa tempat wisata yang ada di Malang, salah satunya adalah Kebun Teh Wonosari. Selama kegiatan outdoor class tersebut, mahasiswa dituntut untuk mendengarkan penjelasan dari guide yang ada di tempat bersejarah maupun tempat wisata. Selain mendengarkan, mahasiswa asing juga diberi tugas untuk mencatat serta merangkum penjelasan dari guide. Selama kegiatan outdoor class, mahasiswa asing juga diminta untuk berkomunikasi dengan masyarakat sekitar di lingkungan tempat sejarah maupun tempat wisata melalui kegiatan wawancara yang merupakan salah satu tugas yang harus dilakukan saat outdoorclass 
berlangsung. Hasil wawancara dengan masyarakat sekitar nantinya akan dipresentasikan di dalam kelas.

Selama pembelajaran di dalam kelas, mahasiswa asing dituntut untuk selalu menggunakan Bahasa Indonesia baik pada pengajar maupun pada teman sejawat. Penggunaan bahasa target, dalam hal ini Bahasa Indonesia penggunaannya dimaksimalkan sehingga mahasiswa asing semakin terlatih dan terbiasa menggunakan bahasa Indonesia. Tidak ada punishment khusus jika mahasiswa menggunakan bahasa selain bahasa Indonesia di dalam kelas, tetapi mahasiswa asing program Darmasiswa yang mayoritas berasal dari Eropa memiliki kesadaran diri bahwa mereka harus memaksimalkan hasil belajar mereka dengan selalu menggunakan bahasa Indonesia dalam aktivitas sehari-hari.

\section{Tingkat Penguasaan Bahasa Kedua Mahasiswa Asing Program Darmasiswa di IKIP Budi Utomo Malang}

Ellis (dalam Chaer, 2003:242) menyebutkan adanya dua tipe pembelajaran bahasa, yaitu tipe naturalistik dan tipe formal di dalam kelas. Tipe naturalistik merupakan pemerolehan bahasa yang berlangsungnya secara alamiah di dalam lingkungan keluarga atau lingkungan tempat tinggal tanpa guru dan tanpa kesengajaan. Berbeda dengan tipe formal berlangsung di dalam kelas dengan guru, materi dan alat bantu belajar yang sudah dipersiapkan. Pembelajaran bahasa yang dilakukan oleh mahasiswa asing program Darmasiswa termasuk pada pembelajaran formal di dalam kelas dan didukung dengan kegiatan outdoor class.

Berdasarkan pengamatan pembelajaran di dalam kelas yang dilakukan oleh peneliti tingkat penguasaan bahasa mahasiswa asing program Darmasiswa meningkat seiring berjalannya waktu. Hal tersebut tampak pada pertambahan kosakata, kemampuan penyusunan kalimat yang sesuai dengan kaidah, pengucapan yang sesuai dengan kaidah berbahasa Indonesia, dan kemampuan mahasiswa asing dalam menyusun teks sederhana.

Dardjowidjojo (2005:244) mengemukakan bahwa ada tiga komponen bahasa yang terdiri atas fonologi, sintaksis, dan semantik. Tingkat penguasaan Bahasa Indonesia mahasiswa asing juga dijabarkan berdasarkan tiga komponen tersebut. Pertama, penguasaan fonologis yang merupakan kemampuan mahasiswa asing dalam mengeluarkan bunyi yang ditandai dengan pengucapan yang sesuai dengan kaidah berbahasa Indonesia. Kedua, penguasaan sintaksis, yaitu dengan memulai berbahasa dengan mengucapkan satu kata dan tataran kalimat. Ketiga, penguasaan semantik yang ditandai dengan tingkat penguasaan tata bahasa.

\section{Representasi Hasil Belajar Mahasiswa Asing Program Darmasiswa di IKIP Budi Utomo Malang}

Representasi hasil belajar mahasiswa asing program Darmasiswa ditandai dengan adanya peningkatan penguasaan bahasa yang sudah ditandai dengan adanya peningkatan dalam tataran fonologis, sintaksis, dan semantik. Berikut adalah uraian yang lebih rinci terkait representasi hasil belajar mahasiswa asing program Darmasiswa di IKIP Budi Utomo Malang.

Pertama, penguasaan fonologis mahasiswa asing ditandai dengan adanya peningkatan kemampuan dalam pengucapan yang sesuai kaidah. Pada bulan pertama mahasiswa asing mengikuti program Darmasiswa, mereka kesulitan dalam pengucapan bunyi 'ng' yang ada di tengah suku kata, misalnya bentuk kata 
'banget' akan diucapkan menjadi 'bangget' atau 'banet' dan bentuk kata 'ulangan' akan diucapkan menjadi 'ulanggan'. Kemudian pada bulan keempat, mahasiswa asing sudah mulai bisa mengucapkan bentuk kata 'banget' sesuai dengan pengucapan yang semestinya walaupun belum sempurna karena masih butuh latihan. Stevick (dalam Ghazali, 2010:114) menjelaskan bahwa penguasaan terhadap pengucapan tampaknya memiliki hubungan erat dengan kondisi afektif dari siswa. Beberapa siswa merasa malu jika mereka dikoreksi di depan temanteman mereka, sehingga mengoreksi sebuah pola wicara yang non-standar bisa jadi merupakan sebuah strategi yang kontra produktif. Sejalan dengan pendapat tersebut, Acton (dalam Ghazali, 2010:2014) mengemukakan bahwa penguasaan terhadap kecermatan pengucapan juga dipengaruhi oleh motivasi siswa untuk beralkuturasi dengan anggota-anggota dari budaya dari bahasa target. Oleh karena pengingkatan pada kemampuan pengucapan tampaknya sangat bergantung pada diri pembelajar sendiri, maka siswa mungkin perlu ditawari untuk melakukan praktik sekian jam per minggu untuk mengatasi bentuk-bentuk wicara non-standar yang sudah terlanjur "memfosil". Oleh karena itu, koreksi pengucapan yang sesuai dengan kaidah dilatihkan secara perlahan dan intensif di dalam maupun di luar kelas. Penguasaan fonologis ini dilatih secara terus menerus pada mata kuliah Berbicara dan Membaca.

Kedua, penguasaan sintaksis ditandai dengan kemampuan mahasiswa asing dalam menyusun kalimat sederhana yang sesuai dengan kaidah bahasa Indonesia. Pada bulan pertama, mahasiswa asing diperkenalkan dengan kata tanya beserta penggunaannya dalam penyusunannya kalimat. Mahasiswa asing juga dilatih dalam menyusun kalimat tanya. Kemudian mahasiswa asing diperkenalkan dengan kalimat aktif dan pasif. Selanjutnya mahasiswa asing juga diperkenalkan dengan kalimat tunggal, majemuk setara, dan majemuk bertingkat. Penguasaan sintaksis ini dilatihkan secara rutin pada mata kuliah Menulis dan Mendengarkan.

Ketiga, penguasaan semantik ditandai dengan penguasaan tata Bahasa Indonesia yang dimiliki oleh mahasiswa asing program Darmasiswa. Pengenalan terhadap sintaksis ini dituangkan dalam mata kuliah Tata Bahasa. Dalam mata kuliah Tata Bahasa ini mahasiswa di-drilling untuk terus berlatih dalam penggunaan tata Bahasa Indonesia yang sesuai dengan kaidah baik dalam bahasa lisan maupun tulisan.

Berdasarkan uraian di atas, dapat dilihat bahwa representasi pemerolehan B2 mahasiswa asing tampak nyata pada kemampuan berbahasa secara produktif. Tingkat kemampuan berbahasa Indonesia mahasiswa asing dapat dilihat jelas pada hasil tulian dan ujaran yang dihasilkannya. Pada minggu awal mahasiswa asing mengikuti program Darmasiswa, para mahasiswa belum mengenal banyak kosakata dalam Bahasa Indonesia. Para mahasiswa asing pun belum mengenal kaidah. Namun, pada semester kedua mahasiswa asing mengikuti program Darmaiswa, mahasiswa sudah mengenal banyak kosakata dan mengenal kaidah dalam berbahasa Indonesia.

\section{KESIMPULAN}


Berdasarkan temuan penelitian dan pembahasan, hasil penelitian dapat disimpulkan secara umum sebagai berikut. Proses pemerolehan bahasa kedua mahasiswa asing dilakukan secara sadar dengan pembelajaran bahasa yang formal dan terstruktur. Selain itu, representasi tingkat penguasaan berbahasa Indonesia mahasiswa asing ditandai dengan penguasaan fonologis, sintaksis, dan semantik.

Secara khusus, hasil penelitian dapat disimpulkan. Pertama, proses pemerolehan bahasa kedua mahasiswa asing program Darmasiswa di IKIP Budi Utomo Malang dilalui dengan belajar bahasa secara sadar, yaitu dengan mengikuti kegiatan belajar mengajar di dalam kelas selama kurang lebih 10 bulan. Selain belajar Bahasa Indonesia secara formal di dalam kelas, mahasiswa asing juga belajar secara nonformal di luar kelas dalam kegiatan outdoor class yang dilaksanakan satu kali dalam sebulan. Kedua, tingkat penguasaan bahasa kedua mahasiswa asing meningkat seiring dengan berjalannya waktu. Hal tersebut dapat dilihat dari hasil pengamatan selama 10 bulan saat berlangsungnya program Darmasiswa. Perkembangan tingkat penguasaan bahasa Indonsesia mahasiswa asing dapat diamati dari hasil tulisan yang tertuang dalam placement test, tugas harian, tes A1, A2, dan B2. Pengamatan dilakukan pada empat aspek keterampilan berbahasa yang terdiri atas membaca, menulis, berbicara, dan mendengarkan.. Ketiga, Representasi hasil belajar mahasiswa asing program Darmasiswa ditandai dengan peningkatan penguasaan fonologis, sintaksis, dan semantik.

\section{SARAN}

Berdasarkan simpulan di atas, saran yang diajukan dirumuskan sebagai berikut. Pengajar Darmasiswa sebaiknya menyesuaikan materi ajar dengan tingkat kemampuan berbahasa mahasiswa asing sehingga proses pemerolehan bahasa kedua dapat berlangsung secara alamiah dalam pembelajaran formal. Kemudian, para pengajar Darmasiswa sebaiknya juga menyusun materi ajar tata bahasa yang disesuaikan dengan teori tahapan pemerolehan bahasa kedua karena saat ini belum tersedia materi ajar tata bahasa dari pihak penyelenggara program Darmasiswa. Selain itu, hasil penelitian ini juga dapat menjadi tumpuan dalam menyusun latihan. Penelitian ini dapat digunakan sebagai masukan bagi penyelenggara program BIPA di IKIP Budi Utomo Malang dalam menentukan materi ajar yang sesuai dengan tingkat kemampuan berbahasa.

\section{DAFTAR RUJUKAN}

Chaer, A. (2003). Psikolinguistik. Jakarta: Rineka Cipta.

Dardjowidjojo, S. (2005). Psikolinguistik: Pengantar Pemahaman Bahasa Manusia. Jakarta: Unika Atma Jaya.

Ghazali, A. S. (2010). Pembelajran Keterampilan Berbahasa dengan Pendekatan Komunikatif Interaktif. Bandung: PT. Refika Aditama.

Kemendikbud. (2015). Program Darmasiswa. (Online), (badanbahasa.kemendikbud.go.id), diakses tanggal 7 Juni 2018.

Suyitno, I. (2017). Norma Pedagogis Pembelajaran Bahasa Indonesia untuk Penutur Asing: Deskripsi Teoretis dan Hasil Kajian Empiris. Bandung: PT. Refika Aditama.

Suyitno, I. (2017). Pembelajaran BIPA Isu Strategis Implikasinya dalam Pembelajaran BIPA. Malang: UM. 
Tarigan, H. G. (2011). Pengajaran Pemerolehan Bahasa. Bandung: Penerbit Angkasa.

Thomas, R. Murray. (2003). Blending Qualitative \& Quantitative Research Methods in Thesis and Dissertations. California: Corwin Press. 